
\title{
JMM $\begin{gathered}\text { JURNAL MAGISTER MANAJEMEN } \\ \text { UNIVERSITAS MATARAM }\end{gathered}$ UNRAM VOL. 6 No. 1 MARET 2017
}

\section{ANALISIS PENGARUH CUSTOMER RELATIONSHIP MARKETING TERHADAP LOYALITAS NASABAH PADA PT. BANK SINARMAS KANTOR CABANG MATARAM}

\author{
Dewa Made Suparwata ${ }^{1}$ \\ Budi Santoso ${ }^{2}$ \\ Dwi Putra Buana Sakti ${ }^{3}$
}

\begin{abstract}
Every company aspires rapid growth in each business unit lived. One thing you can do is to pay attention to aspects of customer loyalty. The purpose of research is to analyze and prove the influence of Trust, Commitment Company, Communication, Conflict Management Customer Loyalty At PT. Bank Sinarmas branch office Mataram. This type of research is the study of causality. The sampling technique used was purposive sampling as many as 170 customers. Analysis of data using multiple linear regression analysis model. The results showed that (1) There is a significant influence of Confidence in Bank Sinarmas Customer Loyalty Branch Mataram. (2) There is a significant influence of the Company's commitment to Customer Loyalty Branch Bank Sinarmas Mataram. (3) There is a significant influence on the Communication on Bank Sinarmas Customer Loyalty Branch Mataram. (4) There is a significant influence of the Conflict Management to Customer Loyalty Branch Bank Sinarmas Mataram. For the management of Bank Sinarmas Branch Mataram, to improve customer loyalty is with the aspect of trust, Corporate Commitment, Communication and Conflict Management for all aspects of this significant effect on customer loyalty.
\end{abstract}

Keywords: Trust, Commitment Company, Communication, Conflict Management, Customer Loyalty

\section{PENDAHULUAN}

Setiap perusahaan mencita-citakan perkembangan yang pesat disetiap unit bisnis yang dijalaninya. Setiap perkembangan yang berarti akan membuahkan hasil berupa keuntungan sebagai penopang pertumbuhan perusahaan untuk terus bersaing dengan para pesaing dalam unit bisnis yang sama. Salah satu yang dapat dilakukan adalah dengan memperhatikan aspek loyalitas pelanggan (Siat, 2004).

Loyalitas pelanggan sangat penting artinya bagi perusahaan yang ingin menjaga kelangsungan hidup usahanya maupun keberhasilan usahanya. Menurut Siat (2004) menyatakan bahwa loyalitas pelanggan merupakan tiket menuju sukses bisnis. Menurut Siat (2004) Loyalitas Nasabah merupakan bentuk tertinggi dari kepuasan konsumen yang menjadi tujuan dari setiap bisnis.

Menurut Fournell (2004) loyalitas merupakan fungsi dari kepuasan pelanggan, rintangan pengalihan, dan keluhan pelanggan. Pelanggan yang puas akan dapat melakukan pembelian ulang pada waktu yang akan datang dan memberitahukan kepada orang lain apa yang dirasakan. Menurut Griffin (2002:31) "Pelanggan yang loyal adalah orang yang melakukan pembelian berulang secara teratur, Membeli antar lini produk dan jasa, mereferensikan kepada orang lain, Menunjukan kekebalan terhadap tarikan dari pesaing".

\footnotetext{
${ }^{1}$ Mahasiswa Program Magister Manajemen Pascasarjana Universitas Mataram.

${ }^{2}$ Dosen Pembimbing Utama, Dosen Program Magister Manajemen Pascasarjana Universitas Mataram.

${ }^{3}$ Dosen Pembimbing Pendamping, Dosen Program Magister Manajemen Pascasarjana Universitas Mataram.
} 


\section{IMM JURnAL MAGISTER MANAJEMEN UNIVERSITAS MATARAM UNRAM VOL. 6 No. 1 MARET 2017}

Beberapa peniliti sebelumnya yang telah melakukan penelitian tentang loyalitas nasabah yaitu Isnalia (2008) menemukan bahwa Customer Relationship Marketing (CRM) mempunyai korelasi positif terhadap tingkat Loyalitas pelanggan. Arifin (2013) menemukan bahwa customer relationship marketing mempengaruhi vatiabel loyalitas. Didik (2005) menemukan bahwa customer relationship marketing berpengaruh positif dan signifikan terhadap kepuasan nasabah dan loyalitas nasabah. Firdani, Indira, dan Fajar (2012) menemukan bahwa CRM berpengaruh terhadap loyalitas pelanggan. Imasari dan Kezia (2011) menemukan bahwa Customer Relationship Management (CRM) mempengaruhi Loyalitas Pelanggan.

Kebanyakan penelitian mengenai Customer relationship marketing selalu menekankan dimensi Trust dan Commitment, hal ini didukung oleh pernyataan Palmetier (2009) dalam Journal of Marketing "Most theories of customer relationship marketing emphasize the role of trust and commitment in affecting performance outcomes". Selain itu Palmatier juga menyatakan Gratitude (rasa syukur) juga ikut mengambil peran dalam mempengaruhi Customer relationship marketing. "Overall, the research empirically demonstrates that gratitude plays an important role in understanding how customer relationship marketing investments increase purchase intentions, sales growth, and share of wallet.".

Dalam jurnal Velnampy dan Sivesan (2012) ada 4 kunci utama dalam customer relationship marketing, yaitu Trust, Equity, Empathy, Commitment. Sedangkan menurut Sivesan (2012) ada 3 dimensi dari customer relationship marketing, diantaranya Trust, Commitment, Communication dan conflict handling. Adapun menurut Saputra dan Ariningsih (2014) dimensi customer relationship marketing meliputi kepercayaan, komitmen, kompetensi, komunikasi, dan kemampuan penanganan konflik. Menurut Chattananon dan Trimetsoontorn (2009), dimensi dari customer relationship marketing adalah Trust, Commitment, Co-operation, Communication, Shared Values, Conflict, Power, Non-opportunistic behavior, Interdependence. Dalam penelitiannya sendiri Chattananon menggunakan Bonding, Empathy, Reciprocity, dan Trust sebagai dimensi dari customer relationship marketing.

Menurut Callaghan et al (1995), Morgan dan Hunt (1994) mengatakan bahwa customer relationship marketing merupakan multidimensi yang terdiri dari enam komponen yaitu kepercayaan, komitmen, komunikasi, membagi nilai, empati, dan timbal balik. Untuk memaksimalkan bisnis kinerja jangka panjang dalam aspek seperti pertumbuhan pelanggan, retensi penjualan dan profitabilitas, harus dibangun, dipelihara dan ditingkatkan hubungan jangka panjang agar saling menguntungkan dengan pembeli sasaran.

Pada penelitian sebelumnya, yaitu Firdani, Indira, dan Fajar (2012) telah menemukan bahwa variabel proses/komunikasi dan teknologi berpengaruh signifikan terhadap loyalitas pelanggan namun, variabel manusia tidak berpengaruh signifikan terhadap loyalitas pelanggan. Oleh sebab itu, dimensi Customer relationship marketing yang akan digunakan dalam penelitian ini adalah Trust, Communication,commitment dan conflict handling.

Salah satu perbankan yang intens meningkatkan loyalitas nasabahnya adalah PT. Sinar Mas Multiartha, Tbk. Pada tahun 2005 PT. Sinar Mas Multiartha, Tbk yang merupakan Kelompok Usaha Sinar Mas yang berada di bawah kelompok usaha Financial Services mengambil alih PT. Bank Shinta Indonesia yang didirikan pada tahun 1989 yang memulai operasionalnya sejak Maret 1990. PT. Bank Shinta Indonesia mengalami perubahan nama menjadi Bank Sinarmas pada Desember 2006. 


\section{IMM JURNAL MAGISTER MANAJEMEN UNIVERSITAS MATARAM UNRAM VOL. 6 No. 1 MARET 2017}

Sebagai upaya untuk memenuhi arahan Bank Indonesia yaitu agar bank-bank umum segera menjadi perusahaan Go Public sehingga sebagian sahamnya dapat dimiliki oleh masyarakat umum, maka pada tahun 2010 setelah mendapatkan pernyataan efektif dari otoritas yang berwenang, tepatnya pada tanggal 13 Desember Bank Sinarmas mencatatkan saham perdananya di Bursa Efek Indonesia sehingga meningkatkan struktur permodalan sebesar 160 miliar rupiah, dari sebelumnya 568 miliar rupiah menjadi 728 miliar rupiah (https://www.banksinarmas.com)

Minat Masyarakat untuk memiliki Saham Bank Sinarmas cukup tinggi, hal ini dikarenakan oleh pertumbuhan usaha yang cukup menggembirakan dan cukup signifikan, hal ini dapat dilihat pada total aset pada akhir Desember 2010 sebesar 11,2 triliun rupiah, jaringan kantor bertambah menjadi 110 Kantor yang tersebar hampir di seluruh provinsi di Indonesia dan telah terhubung secara real time on-line dan teknologi informasi perbankan yang telah dicapai.

Sebagai bank swasta nasional, Bank Sinarmas secara konsisten mengembangkan pangsa pasarnya ditengah tantangan pasar yang sedang berkembang di Indonesia. Usaha dan inisitatif diperlukan untuk memenuhi kebutuhan para nasabah dan masyarakat, maka kegiatan usaha yang awalnya pada pasar pembiayaan usaha kecil, menengah dan mikro berkembang pada pembiayaan konsumer dan komersial.

Tuntutan fasilitas teknologi informasi yang serba canggih di masa kini dan masa depan menjadi tantangan perbankan untuk menyediakan layanan terbaik kepada masyarakat. Oleh karena itu tahun 2007 Bank Sinarmas memfasilitasi teknologi perbankan terintegrasi yang tidak terbatas ruang dan waktu yakni Phone Banking, Internet Banking, dan Automatic Teller Machine (ATM). Keperluan di bidang IT ini dari waktu ke waktu terus dikembangkan seiring dengan keperluan bisnis.

Bank Sinarmas melangkah maju mengembangkan diri secara berkesinambungan dengan semangat dan komitmen yang tinggi dari pemegang saham, pengurus dan karyawan Bank untuk meningkatkan mutu pelayanan dengan standar yang paling tinggi kepada para nasabah dan disertai dengan struktur keuangan yang kuat maka akan menjadikan Bank Sinarmas sebagai Bank Terkemuka di Indonesia.

Dalam aspek customer relationship marketing, Bank Sinarmas selalu berusaha meningkatkan hubungan yang kuat dengan para nasabah dan stakeholder lainnya. Bank Sinarmas terus menerus berjuang mempertahankan nasabah yang ada dan membangun relasi jangka panjang yang mampu mendatangkan laba dengan mereka. Hal ini membuahkan hasil yang terbukti bahwa dari tahun 1998 Modal Disetor Bank Sinarmas sebesar 50 miliar rupiah dan setiap tahun mengalami peningkatan hingga tahun 2013 Modal disetor Bank Sinarmas menjadi 1.299 Miliar rupiah.

Dalam aspek loyalitas nasabah, para nasabah dapat dikatakan memilik loyalitas terhadap Bank Sinarmas. Tercatat hingga September 2013 jumlah NOA Perseroan mencapai 1.043.255 account. Dalam memberikan layanan terhadap nasabah tersebut, Bank Sinarmas memiliki 378 kantor untuk mendekatkan diri dan meningkatkan pelayanan kepada nasabah serta meningkatkan NOA Bank Sinarmas (http://ekbis.sindonews.com)

Dari latar belakang tersebut, maka tujuan penelitian ini adalah "Untuk menganalisis dan membuktikan pengaruh Kepercayaan, Komitmen Perusahaan, Komunikasi, Penanganan Konflik Terhadap Loyalitas Nasabah Pada PT. Bank Sinarmas Kantor Cabang Mataram".

\section{TINJAUAN PUSTAKA}




\section{TMM JURNAL MAGISTER MANAJEMEN UNIVERSITAS MATARAM UNRAM VOL. 6 No. 1 MARET 2017}

Berikut ini disampaikan mengenai landasan secara teoritis tentang masing masing variabel penelitian.

\subsection{Customer relationship marketing}

According to the holistic marketing concept the customer relationship marketing has the aim of building mutually satisfying long term relationships with key parties such as customers, suppliers, distributors and other marketing partners (Kotler and Keller, 2007) Pengertian lain dari customer customer relationship marketing adalah suatu proses untuk menciptakan, mempertahankan dan meningkatkan hubungan-hubungan yang kuat dengan para pelanggan dan stakeholder lainnya. Selain merancang strategi baru untuk menarik pelanggan baru dan menciptakan transaksi dengan mereka, perusahaan terus menerus sedang berjuang mati-matian untuk mempertahankan pelanggan yang ada dan membangun relasi jangka panjang yang mampu mendatangkan laba dengan mereka (Kotler dan Amstrong, 2010).

Sivesan (2012) mengatakan bahwa customer relationship marketing adalah konsep yang sangat penting untuk menarik dan mempertahankan pelanggan dalam sebuah organisasi. Dalam dunia bisnis modern, fokus pemasaran mencerminkan pergerakan perubahan dari pemasaran transaksional ke customer relationship marketing. Membangun, memelihara, dan selalu meningkatkan hubungan pelanggan merupakan aspek penting dari bisnis. Konsep customer relationship marketing secara luas dipahami, baik itu secara akademis dan profesional dimana tujuannya adalah untuk meningkatkan hubungan yang kuat dan menjadikan pelanggan yang acuh tak acuh menjadi loyal.

Tujuan utama customer relationship marketing menurut Sivesan (2012) adalah untuk meningkatkan hubungan yang kuat antara pemasar dan palanggan dengan cara mengkonversi atau menjadikan pelanggan yang acuh tak acuh menjadi lebih loyal. Sisi lain dari tujuan utama customer relationship marketing sebenarnya adalah untuk menemukan lifetime value dari pelanggan. Setelah lifetime value didapat, tujuan selanjutnya adalah bagaimana agar lifetime value masing-masing kelompok pelanggan dapat terus diperbesar dari tahun ketahun. Setelah itu, tujuan ketiganya adalah bagaimana menggunakan profit yang didapat dari dua tujuan pertama untuk mendapatkan pelanggan baru dengan biaya yang relatif murah. Dengan demikian, tujuan jangka panjangnya adalah menghasilkan keuntungan terus menerus dari dua kelompok pelanggan: pelanggan yang sekarang dan pelanggan baru (Chan S, 2003).

Kebanyakan penelitian mengenai Customer relationship marketing selalu menekankan dimensi Trust dan Commitment, hal ini didukung oleh pernyataan Palmetier (2009) dalam Journal of Marketing "Most theories of customer relationship marketing emphasize the role of trust and commitment in affecting performance outcomes". Selain itu Palmatier juga menyatakan Gratitude (rasa syukur) juga ikut mengambil peran dalam mempengaruhi Customer relationship marketing. "Overall, the research empirically demonstrates that gratitude plays an important role in understanding how customer relationship marketing investments increase purchase intentions, sales growth, and share of wallet.".

Dalam jurnal Velnampy dan Sivesan (2012) ada 4 kunci utama dalam customer relationship marketing, yaitu Trust, Equity, Empathy, Commitment. Sedangkan menurut Sivesan (2012) ada 3 dimensi dari customer relationship marketing, diantaranya Trust, Commitment, Communication dan conflict handling. Adapun menurut Saputra dan Ariningsih (2014) dimensi customer relationship marketing meliputi kepercayaan, komitmen, kompetensi, komunikasi, dan kemampuan penanganan konflik. Menurut Chattananon dan Trimetsoontorn (2009), dimensi dari customer relationship marketing adalah Trust, Commitment, Co-operation, Communication, Shared Values, Conflict, Power, Non-opportunistic 


\section{TMM JURNAL MAGISTER MANAJEMEN UNIVERSITAS MATARAM UNRAM VOL. 6 No. 1 MARET 2017}

behavior, Interdependence. Dalam penelitiannya sendiri Chattananon menggunakan Bonding, Empathy, Reciprocity, dan Trust sebagai dimensi dari customer relationship marketing.

\subsection{Kepercayaan}

Kepercayaan secara umum dipandang sebagai unsur mendasar bagi keberhasilan customer relationship marketing. Tanpa adanya kepercayaan suatu hubungan tidak akan bertahan dalam jangka panjang. Morgan dan Hunt (1994) menyatakan kepercayaan sebagai landasan strategi partnership, ketika terdapat pihak-pihak yang mempunyai keinginan untuk komit atau mengikat diri mereka pada suatu hubungan tertentu. Kepercayaan merupakan faktor terbentuknya loyalitas konsumen karena loyalitas konsumen mencakup faktor-faktor kepercayaan dan pengorbanan. loyalitas konsumen tidak akan terbentuk tanpa adanya kepercayaan. Masih menurut Morgan dan Hunt (1994) bahwa kepercayaan secara signifikan mempengaruhi loyalitas nasabah dalam suatu hubungan. Kepercayaan juga merupakan keyakinan yang dimiliki dalam hubungan dengan partner kerja terkait dengan sikap jujur dan saling membantu satu sama lain.

Kepercayaan dapat tercipta ketika suatu pihak merasa nyaman melakukan pertukaran dengan pihak lain yang dengan penuh kejujuran dan dapat dipercaya. Untuk mendapatkan kepercayaan dari pelanggan maka perusahaan harus melakukan komunikasi secara efektif, mengadopsi norma-norma yang diyakini pelanggan, dan menjauhi penilaian yang negatif (Morgan dan Hunt, 1994). Kepercayaan adalah penting karena menyediakan dasar untuk kerjasama masa depan dan keyakinan salah satu pihak yang kebutuhannya akan digenapi di masa depan dengan tindakan yang dilakukan oleh pihak lain. Setelah kepercayaan didirikan, perusahaan belajar untuk mengkoordinasi dan berupaya bersamasama tidak semata-mata untuk kepentingan sendiri.

Kegagalan terbesar dalam hubungan antara konsumen dan pemasar adalah kurangnya kepercayaan (Morgan dan Hunt, 1994). Hubungan konsumen dan perusahaan memerlukan kepercayaan untuk bisa menjadi suatu hubungan jangka panjang (Morgan dan Hunt, 1994) Berdasarkan kepercayaan pelanggan kemungkinan akan merekomendasikan perusahaan kepada pelanggan yang lain, kepercayaan didasarkan pada pengalaman masa lalu dan dijadikan perkiraan untuk perilaku dimasa yang akan datang, kepercayaan dan komitmen memiliki pengaruh dalam menciptakan sebuah nilai bagi pelanggan. Ndubisi (2007) menyatakan bahwa kepercayaan dapat dibangun dengan cara menepati janji terhadap pelanggan, memberikan keamanan pada setiap transaksi yang dilakukan, memberikan pelayanan yang berkualitas, menunjukan sikap peduli terhadap pelanggan, dan memberikan rasa aman. Morgan dan Hunt (1994) berpendapat ketika satu pihak mempunyai keyakinan bahwa pihak lain yang terlibat dalam pertukaran memiliki reliabilitas dan integritas maka dapat dikatakan terdapat kepercayaan.

Kepercayaan merupakan variabel kunci dalam pengembangan keinginan yang kuat untuk mempertahankan sebuah hubungan jangka panjang. Untuk dapat mempertahankan loyalitas pelanggan perusahaan tidak hanya mengandalkan pada kepuasan yang dirasakan oleh pelanggan, tetapi lebih dari itu bahwa kepercayaan merupakan perantara kunci dalam membangun keberhasilan pertukaran hubungan untuk membangun loyalitas pelanggan yang tinggi.

\subsection{Komitmen Perusahaan}

Komitmen merupakan suatu keyakinan antara pihak terkait yang menginginkan adanya hubungan yang terus menerus, dan dinilai penting dalam rangka menjaga hubungan tersebut. Komitmen perusahaan merupakan inti dari customer relationship 


\section{IMM JURNAL MAGISTER MANAJEMEN UNIVERSITAS MATARAM UNRAM VOL. 6 No. 1 MARET 2017}

marketing. Komitmen perusahaan dapat diperoleh dengan cara perusahaan menjadikan pelanggan sebagai prioritas utama, berjangka panjang, dan berdasarkan pada hubungan yang saling menguntungkan. Komitmen perusahaan juga dapat diartikan sebagai janji atau ikrar perusahaan untuk memelihara hubungan yang telah terjalin dengan baik, karena hubungan tersebut memiliki arti penting (Morgan dan Hunt, 1994).

Ndubisi (2007) menyatakan bahwa komitmen perusahaan dapat ditujukan dengan terus menerus melakukan pembelajaran untuk menyediakan kebutuhan pelanggan dan kualitas layanan akan meningkatkan kepuasan dan loyalitas pelanggan, perusahaan menciptakan hubungan yang erat dengan pelanggannya.

\subsection{Komunikasi}

Kinerja suatu perusahaan akan saling terkait dengan pihak-pihak lain. Ketika suatu konflik muncul di dalam suatu perusahaan, penyebabnya selalu diidentifikasikan sebagai hasil dari komunikasi yang kurang baik. Perusahaan harus mengelola komunikasi dengan baik karena komunikasi yang gagal kemungkinan dapat menyebabkan hal yang merugikan seperti kesalahpahaman atau kebingungan. Keefektifan komunikasi merupakan kemudahan mendapatkan informasi yang benar dan tepat sehingga pelanggan yang ingin melakukan transaksi dapat secara langsung mengambil keputusan untuk memilih sesuai dengan kebutuhannya, ketepatan informasi yang diperoleh secara tidak langsung dapat mempengaruhi loyalitas pelanggan Assael (2004). Komunikasi merupakan sarana yang sangat penting ketika ingin membangun hubungan dengan seseorang. Komunikasi merupakan alat perekat hubungan antara perusahaan dengan pelanggannya, sehingga komunikasi mempunyai peran vital dalam membina hubungan. Perusahaan yang orientasinya berusaha memenuhi keinginan dan kebutuhan pelanggan serta berusaha mendapatkan keuntungan yang berkelanjutan sangat membutuhkan peran komunikasi.

Kelangsungan hubungan tergantung pada cara berkomunikasi. Keberhasilan sebuah komunikasi dapat dipengaruhi oleh beberapa hal, antara lain kejelasan ide yang ingin disampaikan, kesamaan persepsi antara pengirim dan penerima informasi, tidak adanya distorsi, dan saluran komunikasi yang tepat. Proses komunikasi juga mempengaruhi kesuksesan hubungan antara perusahaan dengan pelanggannya. Assael (2004) menyatakan bahwa proses komunikasi pemasaran terdiri atas lima tahap, yaitu:

a) Sumber pesan; Pertama kali pesan komunikasi berasal dari sumber yaitu pihak yang mengirim pesan pemasaran kepada pelanggan. Agar keefektifan komunikasi personal tercapai perlu mempertimbangkan kredibilitas sumber.

b) Encoding; merupakan keseluruhan proses dari perancangan pesan sampai penentuan jenis promosi yang akan digunakan.

c) Transmisi; yaitu proses penyampaian pesan melalui media.

d) Decoding; yaitu proses dimana penerima pesan memberikan respon dan menginterpretasikan pesan yang diterima.

e) Tindakan; pemasar mengevaluasi apakah pesan yang disampaikan sesuai dengan harapan, artinya mendapatkan respon yang dan tindakan yang positif dari konsumen, atau justru pesan tidak sampai secara efektif.

Komunikasi dalam customer relationship marketing berhubungan dengan nilai yang diperoleh pelanggan, memberikan informasi yang tepat dan dapat dipercaya serta informasi mengenai adanya perubahan jasa yang ditawarkan, dan komunikasi yang proaktif ketika terjadi masalah antara perusahaan dan pelanggan. Pelanggan selalu menginginkan terciptanya komunikasi yang efektif dengan perusahaan, komunikasi yang baik tentunya dapat meningkatkan kepercayaan pelanggan terhadap perusahaan. Melalui komunikasi, 


\section{IMM JURnAL MAGISTER MANAJEMEN UNIVERSITAS MATARAM UNRAM VOL. 6 No. 1 MARET 2017}

pelanggan juga dapat mengemukakan ketidakpuasannya sehingga dapat dijadikan acuan bagi perusahaan untuk memperbaiki kinerjanya. Jika customer relationship marketing ingin berhasil maka harus menyertakan semua pesan yang ada dalam komunikasi pemasaran, hal ini diperlukan dalam menciptakan, memelihara, dan memperluas hubungan dengan pelanggan. Komunikasi melibatkan paling sedikit dua orang atau lebih dengan menggunakan cara komunikasi yang biasa dilakukan oleh seseorang seperti lisan, tulisan, maupun sinyal-sinyal nonverbal seperti symbol, warna ataupun ekspresi wajah. Ball et al. (2004), mengungkapkan bahwa komunikasi dapat dilakukan melalui komunikasi tertulis seperti surat menyurat, e-mail, web site, atau interaksi lainnya seperti komunikasi secara langsung dengan para karyawan perusahaan sebelum, selama, dan setelah melakukan transaksi.

\subsection{Penanganan Konflik}

Dalam setiap hubungan sosial maupun ekonomi selalu terdapat rasa saling ketergantungan diantara semua pihak. Perusahaan dan pelanggan yang saling bergantung harus dapat menciptakan hubungan yang saling mendukung satu sama lain, namun pada kenyataanya hubungan yang saling bergantung tersebut dapat menciptakan konflik yang disebabkan oleh berbagai macam hal. Hal-hal yang berpotensi menimbulkan konflik tidak hanya hal-hal yang berkaitan dengan produk, namun juga berkaitan dengan pelayanan, keramahan (courtesy), sikap sopan santun, perhatian dan sikap kepedulian dari karyawan atau penyedia jasa tersebut. Kemampuan penanganan konflik mengacu pada kemampuan perusahaan untuk mencegah atau meminimalkan dampak dari hal-hal yang potensial dapat menimbulkan konflik, dan kemampuan menyelesaikan konflik nyata yang sudah terjadi. Konflik dapat menjadi masalah yang serius di dalam perusahaan dan kemungkinan berpotensi menurunkan kinerja jika konflik tersebut dibiarkan berlarut-larut tanpa penyelesaian. Penanganan konflik merupakan tindakan khusus pada saat melakukan interaksi dengan pelanggan (Ball et al., 2004). Kemampuan pihak perusahaan dalam menangani konflik dengan baik akan memberikan kepuasan pada pelanggan dan menyebabkan pelanggan menjadi loyal (Ndubisi, 2009).

Sivesan (2012) menyatakan bahwa jika suatu perusahaan dapat dipercaya, berkomitmen untuk layanan, dapat diandalkan, efisien dalam berkomunikasi dengan pelanggan, dan mampu menangani konflik dengan baik, maka konsumen akan cenderung untuk setia terhadap produk. Sivesan juga menyarankan bahwa perusahaan harus menjaga hubungan baik dengan para pelanggannya untuk mendapatkan loyalitas.

\subsection{Loyalitas Nasabah}

Loyalitas pelanggan sangat penting artinya bagi perusahaan yang ingin menjaga kelangsungan hidup usahanya maupun keberhasilan usahanya. Menurut (Siat, 2004:297) menyatakan bahwa loyalitas pelanggan merupakan tiket menuju sukses bisnis. Menurut (Siat, 2004:298) Loyalitas Nasabah merupakan bentuk tertinggi dari kepuasan konsumen yang menjadi tujuan dari setiap bisnis.

Loyalitas Nasabah menurut Reichheld (1996, dalam East et al., 2000) merupakan tingkatan dimana konsumen akan tetap menggunakan suatu merek atau produsen tertentu. Adanya loyalitas pelanggan akan suatu produk/ jasa, dapat memberikan perlindungan bagi perusahaan dari persaingan dan memberikan lebih banyak kontrol dalam membuat rencana program-program pemasaran yang akan dijalankan oleh perusahaan tersebut. Sementara menurut Oliver (1993, dalam Yin Lam et al., 2004), Loyalitas Nasabah didefinisikan sebagai komitmen pembeli terhadap suatu produk, jasa, merek, atau organisasi. Loyalitas juga dapat didefinisikan sebagai emosi yang positif, 


\section{IMM JURnal MAGISTER MANAJEMEN UNIVERSITAS MATARAM UNRAM VOL. 6 No. 1 MARET 2017}

evaluatif, dan atau respons dari kecenderungan perilaku terhadap suatu merek, label, atau alternatif yang dapat dipilah oleh seseorang dalam kapasitasnya sebagai seorang pengguna, pengambil keputusan, ataupun sebagai purchasing agent (Sheth, 1974).

Menurut Aaker (dalam Joko Riyadi 1999: 58) faktor-faktor yang mempengaruhi kesetiaan konsumen sebagai berikut :

a) Kepuasan (Satisfaction)

Konsumen akan loyal terhadap suatu produk bila ia mendapatkan kepuasan dari produk tersebut. Karena itu, bila konsumen mencoba beberapa macam produk melampaui kriteria kepuasan kepuasan produk atau tidak. Bila setelah mencoba dan responnya baik, maka berarti konsumen tersebut puas sehingga akan memutuskan membeli produk tersebut secara konsisten sepanjang waktu. Ini berarti telah tercipta kesetiaan konsumen terhadap produk tersebut.

b) Perilaku Kebiasaan (Habitual Behavior)

Kesetiaan konsumen dapat dibentuk karena kebiasaan konsumen. Apabila yang dilakukan sudah merupakan kebiasaan, maka pembeli tersebut tidak melalui tidak lagi melalui pengambilan keputusan yang panjang. Pada kondidi ini, dapat dikatakan bahwa konsumen akan tetap membeli produk tersebut, yaitu konsumen akan tetap membeli produk yang sama untuk suatu jenis produk dan cenderung tidak berganti-ganti produk.

c) Komitmen (Commitment)

Dalam suatu produk yang kuat terdapat konsumen yang memiliki komitmen dalam jumlah yang banyak. Kesetiaan konsumen akan timbul bila ada kepercayaan dari konsumen terhadap produk-produk sehingga ada komunikasi dan interaksi diantara konsumennya, yaitu dengan membicarakan produk tersebut.

d) Kesukaan Produk (Linking of The Brand)

Kesetiaan yang terbentuk dan dipengaruhi oleh tingkat kesetiaan konsumen secara umum. Tingkat kesetiaan tersebut dapat diukur mulai timbulnya kesukaan terhadap produk sampai ada kepercayaan dari produk tersebut berkenaan dari kinerja dari produk-produk tersebut. Konsumen yang dikatakan loyal adalah konsumen yang berulang kali membeli produk tersebut bukan karena adanya penawaran khusus, tetapi karena konsumen percaya terhadap produk tersebut memiliki kualitas yang sama sehingga member tingkatan yang sama pada produknya.

e) Biaya Pengalihan (Switching Cost)

Adanya perbedaan pengorbanan dan atau resiko kegagalan, biaya, energi, dan fisik yang dikeluarkan konsumen karena dia memilih salah satu alternatif. Bila biaya pengalihan besar, maka konsumen akan berhati-hati untuk berpindah ke produk yang lain karena resiko kegagalan yang juga besar sehingga konsumen cenderung loyal. 


\section{$\int M M$ JURNAL MAGISTER MANAJEMEN UNRAM VOL. 6 No. 1 MARET 2017}

\subsection{Kerangka Konseptual Penelitian}

Kerangka penelitian ini sebagai berikut ini :

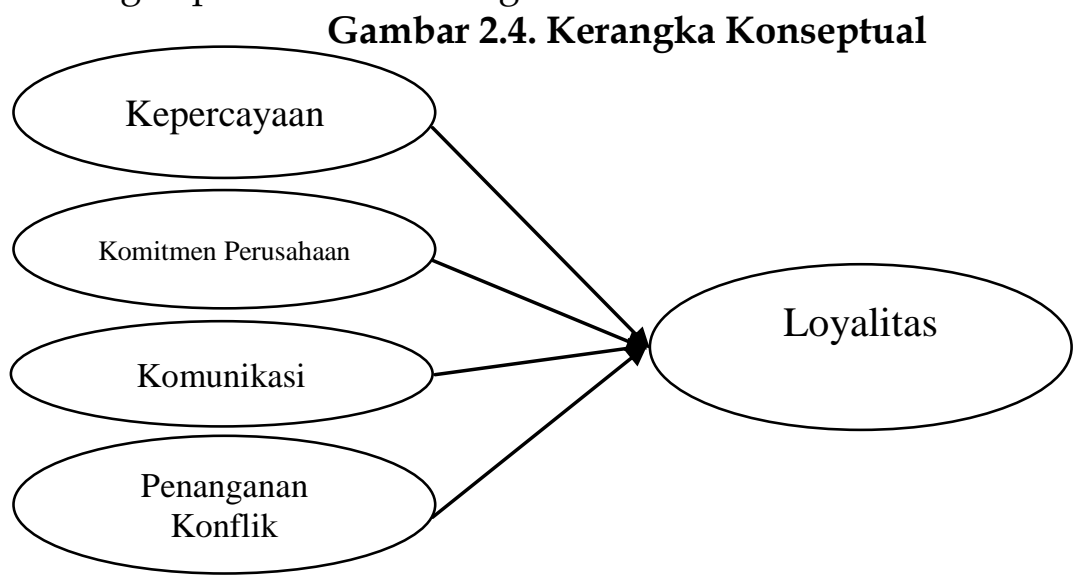

Gambar 2.4. Kerangka Konseptual Penelitian

\section{METODE PENELITIAN}

Jenis Penelitian ini adalah penelitian asosiatif. Menurut Silalahi (2010:33) "Penelitian asosiatif merupakan penelitian yang bertujuan untuk mengetahui hubungan sebab akibat dari dua variabel atau lebih". Jenis penelitian asosiatif yang digunakan dalam penelitian ini diharapkan akan memberikan rumusan untuk menemukan pengaruh dari Customer Relationship Marketing Terhadap Loyalitas Nasabah Pada PT. Bank Sinarmas Kantor Cabang Mataram. Populasi dalam penelitian ini adalah semua nasabah yang terdaftar aktif sebagai nasabang funding dan landing pada PT. Bank Sinarmas Kantor Cabang Mataram. Sementara sampel yang dipilih yaitu konsumen yang telah menjadi nasabah minimal dua tahun di PT. Bank Sinarmas Kantor Cabang Mataram pada saat pengambilan data dilakukan oleh penulis. Karena adanya keterbatasan waktu, tenaga, dan biaya, batasan jumlah sampel yang diambil dari seluruh populasi adalah sebanyak lima sampai sepuluh (5-10) dikali jumlah indikator dari variabel bebas yang diteliti (Malhotra: 1993)

Jadi, atas dasar kriteria tersebut diatas dapat ditentukan jumlah sampel minimal yang diambil adalah :

$$
\begin{aligned}
& n=10 \times i=\text { sampel } \\
& n=10 \times 17=170 \text { sampel }
\end{aligned}
$$

Keterangan:

$\mathrm{n}=$ ukuran sampel

$\mathrm{i}=$ Jumlah indikator variabel bebas yang diteliti

Dari hasil perhitungan rumus diatas dapat diperoleh jumlah sampel yang akan diteliti adalah sebanyak 170 responden.

Alat analisis yang digunakan dalam pembuktian hipotesis yang telah diajukan adalah Analisis Regresi Berganda dengan uji t sebagai metode pengujian ini digunakan untuk menguji derajat keyakinan antara variabel yang diteliti secara parsial dengan perasamaan sebagai berikut (Priyatno, 2008:70): 


\section{JURNAL MAGISTER MANAJEMEN
UNIVERSITAS MATARAM UNRAM VOL. 6 No. 1 MARET 2017}

$$
\text { thitung }=\frac{b 1}{s e(b 1)}
$$

Dimana:

t hitung $=$ uji koefisien regresi ganda secara persial

se $\quad=$ standar eror

$\mathrm{b}_{1} \quad=$ nilai koefisien $\mathrm{X}$. Untuk menguji t hitung,

Pengujian dapat dilakukan dengan menggunakan signifikan level $\quad \alpha=5 \%$ atau sesuai dengan level signifikansi yang digunakan, sedangkan penerimaan atau penolakan hipotesis pada level signifikansi $\alpha=5 \%$.

\section{HASIL PENELITIAN}

\subsection{Deskripsi Variabel Penelitian}

1) Kepercayaan (X1)

Kepercayaan adalah tanggapan responden terhadap keyakinan yang dimiliki dalam hubungan nasabah dengan perusahaan. Indikator variabel ini adalah (1) menepati janji terhadap pelanggan, (2) memberikan keamanan pada setiap transaksi yang dilakukan, (3) memberikan pelayanan yang berkualitas, (4) menunjukan sikap peduli terhadap pelanggan, dan (5) memberikan rasa aman. Pernyataan yang diajukan untuk variabel ini sebanyak 5 item pernyataan.

rata-rata total dari Kepercayaan dari tanggapan responden sebesar 3,47 dengan kriteria tinggi. Kriteria ini menunjukkan bahwa seluruh Nasabah di Bank Sinarmas Cabang Mataram memiliki kepercayaan yang tinggi terhadap perusahaan. Bank Sinarmas dapat memberikan rasa aman kepada nasabahnya, mampu menunjukan sikap peduli terhadap pelanggan, Bank Sinarmas juga dapat memberikan pelayanan yang berkualitas, memberikan keamanan pada setiap transaksi yang dilakukan, serta selalu berorientasi untuk dapat menepati janji terhadap pelanggannya.

\section{2) Komitmen Perusahaan (X2)}

Komitmen Perusahaan merupakan tanggapan responden terhadap sikap dan perilaku perusahaan untuk memelihara hubungan yang telah terjalin dengan baik dengan nasabah. Indikator variabel ini adalah (1) terus menerus melakukan pembelajaran untuk menyediakan kebutuhan pelanggan (2) terus menerus meningkatkan kualitas layanan dan (3) perusahaan menciptakan hubungan yang erat dengan pelanggan. Pernyataan yang diajukan untuk variabel ini sebanyak 3 item pernyataan.

Rata-rata total dari Komitmen perusahaan dari tanggapan responden sebesar 3,26 dengan kriteria cukup tinggi. Kriteria ini menunjukkan bahwa Nasabah di Bank Sinarmas Cabang Mataram merasa bahwa perusahaan dapat menjalin hubungan dengan cukup efektif dengan mereka. Bank Sinarmas selama ini secara terus menerus melakukan pembelajaran untuk menyediakan segala kebutuhan dari pelanggannya, terus menerus meningkatkan kualitas layanan, dan menciptakan hubungan yang erat dengan pelanggannya.

\section{3) Komunikasi (X3)}

Komunikasi merupakan tanggapan responden terhadap sarana yang digunakan perusahaan untuk membangun hubungan dengan nasabah. Indikator variabel ini adalah (1) Memberikan informasi yang tepat dan dapat dipercaya (2) Penyampaian informasi mengenai adanya perubahan jasa yang ditawarkan, 


\section{JURNAL MAGISTER MANAJEMEN
UNIVERSITAS MATARAM UNRAM VOL. 6 No. 1 MARET 2017}

Komunikasi yang proaktif ketika terjadi masalah antara perusahaan dan pelanggan. Rata-rata total dari komunikasi berdasarkan tanggapan responden sebesar 3,14 dengan kriteria cukup efektif. Kriteria ini menunjukkan bahwa perusahaan sudah cukup efektif dalam membangun hubungan baik dengan nasabah mereka. Bank Sinarmas memberikan informasi yang tepat dan dapat dipercaya, menyampaikan informasi mengenai adanya perubahan jasa yang ditawarkan, dan melakukan komunikasi yang proaktif ketika terjadi masalah antara perusahaan dan pelanggan.

4) Penanganan Konflik (X4)

Penanganan Konflik merupakan tanggapan responden terhadap kemampuan perusahaan untuk mencegah atau meminimalkan dampak dari hal-hal yang potensial dapat menimbulkan konflik, dan kemampuan menyelesaikan konflik nyata yang sudah terjadi. Indikator variabel ini adalah (1) Mencegah hal-hal yang dapat menimbulkan konflik dalam memberikan pelayanan, (2) Kemampuan meminimalkan dampak dari konflik yang timbul, (3) Kemampuan menyelesaikan konflik nyata yang sudah terjadi. Pernyataan yang diajukan untuk variabel ini sebanyak 3 item pernyataan. Rata-rata total dari penanganan konflik dari tanggapan responden sebesar 3,42 dengan kriteria cukup efektif. Kriteria ini menunjukkan bahwa perusahaan sudah cukup efektif dalam mencegah atau meminimalkan konflik yang terjadi dengan nasabah mereka. Bank Sinarmas mencegah hal-hal yang dapat menimbulkan konflik dalam memberikan pelayanan, mampu meminimalkan dampak dari konflik yang timbul, dan mampu menyelesaikan konflik nyata yang sudah terjadi.

5) Loyalitas Nasabah (Y)

Loyalitas Nasabah adalah tanggapan responden terhadap dorongan yang ada pada dirinya untuk melaksanakan pekerjaan pada Bank Sinarmas Cabang Mataram. Pernyataan yang diajukan untuk variabel ini sebanyak 3 item pernyataan. Adapun rata-rata total dari Loyalitas Nasabah berdasarkan tanggapan responden sebesar 3,90 dengan kriteria tinggi. Kriteria ini menunjukkan bahwa Nasabah Bank Sinarmas Cabang Mataram memiliki Loyalitas Nasabah yang tinggi. Bank Sinarmas mampu membangun kesetiaan nasabahnya terhadap perusahaan, mampu membangun ketahanan terhadap pengaruh yang negatif mengenai perusahaan, dan Bank Sinarmas memiliki kelebihan dibandingkan dengan bank lainnya, sehingga kelebihan inilah yang direkomendasi oleh nasabahnya kepada orang lain.

\subsection{Hasil Uji Signifikansi Parsial (Uji t)}

Untuk melihat bagaimana pengaruh secara parsial dari Kepercayaan, Komitmen Perusahaan, Komunikasi, Penanganan Konflik, dan Prospek Karir terhadap Loyalitas Nasabah Bank Sinarmas Cabang Mataram digunakan uji t.

Tabel 4.14. Hasil Uji t variabel bebas terhadap variabel terikat

\begin{tabular}{|ll|r|r|r|r|r|}
\hline \multirow{2}{*}{ Model } & \multicolumn{2}{|c|}{$\begin{array}{c}\text { Unstandardized } \\
\text { Coefficients }\end{array}$} & $\begin{array}{c}\text { Standardized } \\
\text { Coefficients }\end{array}$ & & \\
\cline { 3 - 5 } & & \multicolumn{1}{c|}{ B } & Std. Error & \multicolumn{1}{c|}{ Beta } & \multicolumn{1}{c|}{ t } & \multicolumn{1}{c|}{ Sig. } \\
\hline 1 & (Constant) & 1,101 &, 201 & & 5,467 &, 000 \\
& Kepercayaan &, 252 &, 052 &, 309 & 4,810 &, 000 \\
& Komitmen Perusahaan &, 207 &, 054 &, 233 & 3,827 &, 000 \\
& Komunikasi &, 211 &, 061 &, 227 & 3,441 &, 001 \\
& Penanganan Konflik &, 132 &, 029 &, 244 & 4,478 &, 000 \\
\hline
\end{tabular}

a. Dependent Variable: Loyalitas Nasabah 


\section{IMM JURnAL MAGISTER MANAJEMEN UNIVERSITAS MATARAM UNRAM VOL. 6 No. 1 MARET 2017}

Dengan menggunakan tingkat keyakinan 95\% dimana a=5\%, df (degree fredom) $\mathrm{n}-1=170-1=169$, sehingga diperoleh hasil untuk $\mathrm{t}$ tabel sebesar 1,974. Sehingga karena $\mathrm{t}$ hitung Kepercayaan $>\mathrm{t}$ tabel 4,810>1,974), $\mathrm{t}$ hitung Komitmen Perusahaan $>\mathrm{t}$ tabel $(3,827>1,974)$, $\mathrm{t}$ hitung Komunikasi $>\mathrm{t}$ tabel $(3,441>1,974)$, $\mathrm{t}$ hitung Penanganan Konflik $>\mathrm{t}$ tabel $(4,478>1,974)$ maka dapat disimpulkan bahwa terdapat pengaruh yang signifikan secara parsial dari Kepercayaan, Komitmen Perusahaan, Komunikasi, Penanganan Konflik terhadap Loyalitas Nasabah Bank Sinarmas Cabang Mataram. Sehingga dapat disimpulkan bahwa hipotesa kedua $\left(\mathrm{H}_{2}\right)$ yang menyatakan bahwa "Terdapat pengaruh yang signifikan secara parsial dari Kepercayaan, Komitmen Perusahaan, Komunikasi dan Penanganan Konflik terhadap Loyalitas Nasabah Bank Sinarmas Cabang Mataram."

\subsection{Hasil Pengujian Hipotesis}

Berdasarkan kajian hasil analisis data di atas, maka dapat dirumuskan hasil pengujian hipotesis yang telah diajukan berikut ini.

1) Hipotesis Pertama (H1) dalam Penelitian ini menyatakan "Kepercayaan mempunyai pengaruh positif dan signifikan terhadap loyalitas nasabah". Pembuktian hipotesis ini dilakukan dengan analisis uji $\mathrm{T}$ yang menunjukkan bahwa $\mathrm{t}$ hitung Kepercayaan $>\mathrm{t}$ tabel $(4,810>1,974)$, yang berarti signifikan. Sehingga dapat disimpulkan bahwa terdapat pengaruh yang positif dari Kepercayaan mempunyai pengaruh positif dan signifikan terhadap loyalitas nasabah Sehingga hipotesis pertama diterima.

2) Hipotesis Kedua (H2) dalam Penelitian ini menyatakan "Komitmen Perusahaan mempunyai pengaruh positif dan signifikan terhadap loyalitas nasabah". Pembuktian hipotesis ini dilakukan dengan analisis uji $\mathrm{T}$ yang menunjukkan bahwa $\mathrm{t}$ hitung Komitmen Perusahaan $>t$ tabel $(3,827>1,974)$, yang berarti signifikan. Sehingga dapat disimpulkan bahwa terdapat pengaruh yang positif dari Komitmen Perusahaan terhadap loyalitas nasabah, sehingga hipotesis kedua diterima.

3) Hipotesis Ketiga (H3) dalam Penelitian ini menyatakan "Komunikasi mempunyai pengaruh positif dan signifikan terhadap loyalitas nasabah". Pembuktian hipotesis ini dilakukan dengan analisis uji $\mathrm{T}$ yang menunjukkan bahwa $\mathrm{t}$ hitung Komunikasi $>\mathrm{t}$ tabel $(3,441>1,974)$, yang berarti signifikan. Sehingga dapat disimpulkan bahwa terdapat pengaruh yang positif dari Komunikasi terhadap loyalitas nasabah. Sehingga hipotesis ketiga dapat diterima.

4) Hipotesis Keempat (H4) dalam Penelitian ini menyatakan "Penanganan Konflik mempunyai pengaruh positif dan signifikan terhadap loyalitas nasabah". Pembuktian hipotesis ini dilakukan dengan analisis Uji $\mathrm{T}$ yang menunjukkan bahwa $\mathrm{t}$ hitung Penanganan Konflik $>\mathrm{t}$ tabel $(4,478>1,974)$ yang berarti signifikan. Sehingga dapat disimpulkan bahwa terdapat pengaruh yang positif dari Penanganan Konflik terhadap loyalitas nasabah. Sehingga hipotesis keempat dapat diterima.

\section{PEMBAHASAN}

1) Pengaruh Kepercayaan Terhadap Loyalitas Nasabah

Kegagalan terbesar dalam hubungan antara konsumen dan pemasar adalah kurangnya kepercayaan (Morgan dan Hunt, 1994). Kepercayaan merupakan variabel kunci dalam pengembangan keinginan yang kuat untuk mempertahankan sebuah hubungan jangka panjang. Untuk dapat mempertahankan loyalitas pelanggan perusahaan tidak hanya mengandalkan pada kepuasan yang dirasakan oleh 


\section{IMM JURNAL MAGISTER MANAJEMEN UNIVERSITAS MATARAM UNRAM VOL. 6 No. 1 MARET 2017}

pelanggan, tetapi lebih dari itu bahwa kepercayaan merupakan perantara kunci dalam membangun keberhasilan pertukaran hubungan untuk membangun loyalitas pelanggan yang tinggi.

Penelitian yang dilakukan oleh Zulganef (2002) dalam Setiawan dan Ukudi (2007) membuktikan bahwa kepercayaan mempunyai pengaruh terhadap loyalitas pelanggan pada perusahaan yang menggunakan kartu kredit. Ramadania, 2002 dalam Setiawan dan Ukudi (2007), membuktikan hipotesis bahwa Kepercayaan mempunyai pengaruh positif dan signifikan terhadap loyalitas nasabah. Setiawan dan Ukudi (2007) Fasocah dan Hartono (2013), Nidyatantari, Suryawardani, dan Agung (2016) menemukan bahwa kepercayaan memilikii pengaruh yang signifikan terhadap loyalitas nasabah.

2) Pengaruh Komitmen Perusahaan Terhadap Loyalitas Nasabah

Komitmen merupakan suatu keyakinan antara pihak terkait yang menginginkan adanya hubungan yang terus menerus, dan dinilai penting dalam rangka menjaga hubungan tersebut. Komitmen perusahaan merupakan inti dari customer relationship marketing. Komitmen perusahaan dapat diperoleh dengan cara perusahaan menjadikan pelanggan sebagai prioritas utama, berjangka panjang, dan berdasarkan pada hubungan yang saling menguntungkan. Ndubisi (2007) menyatakan bahwa komitmen perusahaan dapat ditujukan dengan terus menerus melakukan pembelajaran untuk menyediakan kebutuhan pelanggan dan kualitas layanan akan meningkatkan kepuasan dan loyalitas pelanggan, perusahaan menciptakan hubungan yang erat dengan pelanggannya.

Penelitian yang dilakukan oleh Setiawan dan Ukudi (2007) menemukan bahwa komitmen memilikii pengaruh yang signifikan terhadap loyalitas nasabah. Setyawan (2013) menemukan bahwa komitmen memilikii pengaruh yang signifikan terhadap loyalitas nasabah.

\section{3) Pengaruh Komunikasi Terhadap Loyalitas Nasabah}

Perusahaan harus mengelola komunikasi dengan baik karena komunikasi yang gagal kemungkinan dapat menyebabkan hal yang merugikan seperti kesalahpahaman atau kebingungan. Keefektifan komunikasi merupakan kemudahan mendapatkan informasi yang benar dan tepat sehingga pelanggan yang ingin melakukan transaksi dapat secara langsung mengambil keputusan untuk memilih sesuai dengan kebutuhannya, ketepatan informasi yang diperoleh secara tidak langsung dapat mempengaruhi loyalitas pelanggan Assael (2004).

Penelitian yang telah dilakukan oleh Supit, Mandey, dan Moniharapon (2015) menemukan bahwa komunikasi memiliki pengaruh yang signifikan terhadap loyalitas nasabah. Enjelita (2013) menemukan bahwa komunikasi memiliki pengaruh yang signifikan terhadap loyalitas nasabah. Arifin (2013) menemukan bahwa komunikasi memiliki pengaruh yang positif terhadap loyalitas nasabah.

4) Pengaruh Penanganan Konflik Terhadap Loyalitas Nasabah

Perusahaan dan pelanggan yang saling bergantung harus dapat menciptakan hubungan yang saling mendukung satu sama lain, namun pada kenyataanya hubungan yang saling bergantung tersebut dapat menciptakan konflik yang disebabkan oleh berbagai macam hal. Hal-hal yang berpotensi menimbulkan konflik tidak hanya hal-hal yang berkaitan dengan produk, namun juga berkaitan dengan pelayanan, keramahan (courtesy), sikap sopan santun, perhatian dan sikap kepedulian dari karyawan atau penyedia jasa tersebut. 


\section{IMM JURnal MAGISTER MANAJEMEN UNIVERSITAS MATARAM UNRAM VOL. 6 No. 1 MARET 2017}

Kemampuan penanganan konflik mengacu pada kemampuan perusahaan untuk mencegah atau meminimalkan dampak dari hal-hal yang potensial dapat menimbulkan konflik, dan kemampuan menyelesaikan konflik nyata yang sudah terjadi. Konflik dapat menjadi masalah yang serius di dalam perusahaan dan kemungkinan berpotensi menurunkan kinerja jika konflik tersebut dibiarkan berlarut-larut tanpa penyelesaian. Penanganan konflik merupakan tindakan khusus pada saat melakukan interaksi dengan pelanggan (Ball et al., 2004). Kemampuan pihak perusahaan dalam menangani konflik dengan baik akan memberikan kepuasan pada pelanggan dan menyebabkan pelanggan menjadi loyal (Ndubisi, 2009).

Penelitian yang dilakukan oleh Supit, Mandey, dan Moniharapon (2015) menemukan bahwa penanganan konflik memiliki pengaruh yang signifikan terhadap loyalitas nasabah. Safitri (2013) menemukan bahwa penanganan konflik memiliki pengaruh yang positif terhadap loyalitas nasabah. Herdian dan Widyastuti (2013) menemukan bahwa penanganan konflik memiliki pengaruh yang positif terhadap loyalitas nasabah.

\section{KESIMPULAN}

Dari hasil penelitian dan pembahasaan di atas, maka kesimpulan dari penelitian yang dapat diambil adalah :

(1) Tanggapan responden terhadap Kepercayaan berada pada kriteria tinggi. Kriteria ini menunjukkan bahwa seluruh Nasabah di Bank Sinarmas Cabang Mataram memiliki kepercayaan yang tinggi terhadap perusahaan. Bank Sinarmas dapat memberikan rasa aman kepada nasabahnya, mampu menunjukan sikap peduli terhadap pelanggan, Bank Sinarmas juga dapat memberikan pelayanan yang berkualitas, memberikan keamanan pada setiap transaksi yang dilakukan, serta selalu berorientasi untuk dapat menepati janji terhadap pelanggannya.

(2) Tanggapan responden terhadap Komitmen perusahaan berada pada kriteria cukup efektif. Kriteria ini menunjukkan bahwa Nasabah di Bank Sinarmas Cabang Mataram merasa bahwa perusahaan dapat menjalin hubungan dengan cukup efektif dengan mereka. Bank Sinarmas selama ini secara terus menerus melakukan pembelajaran untuk menyediakan segala kebutuhan dari pelanggannya, terus menerus meningkatkan kualitas layanan, dan menciptakan hubungan yang erat dengan pelanggannya.

(3) Tanggapan responden terhadap komunikasi berada pada kriteria cukup efektif. Kriteria ini menunjukkan bahwa perusahaan sudah cukup efektif dalam membangun hubungan baik dengan nasabah mereka. Bank Sinarmas memberikan informasi yang tepat dan dapat dipercaya, menyampaikan informasi mengenai adanya perubahan jasa yang ditawarkan, dan melakukan komunikasi yang proaktif ketika terjadi masalah antara perusahaan dan pelanggan.

(4) Tanggapan responden terhadap penanganan konflik berada pada kriteria cukup efektif. Kriteria ini menunjukkan bahwa perusahaan sudah cukup efektif dalam mencegah atau meminimalkan konflik yang terjadi dengan nasabah mereka. Bank Sinarmas mencegah hal-hal yang dapat menimbulkan konflik dalam memberikan pelayanan, mampu meminimalkan dampak dari konflik yang timbul, dan mampu menyelesaikan konflik nyata yang sudah terjadi. 


\section{JMM $\begin{gathered}\text { JURNAL MAGISTER MANAJEMEN } \\ \text { UNIVERSITAS MATARAM }\end{gathered}$ UNRAM VOL. 6 No. 1 MARET 2017}

(5) Tanggapan responden terhadap Loyalitas berada pada kriteria tinggi. Kriteria ini menunjukkan bahwa Nasabah Bank Sinarmas Cabang Mataram memiliki Loyalitas Nasabah yang tinggi. Bank Sinarmas mampu membangun kesetiaan nasabahnya terhadap perusahaan, mampu membangun ketahanan terhadap pengaruh yang negatif mengenai perusahaan, dan Bank Sinarmas memiliki kelebihan dibandingkan dengan bank lainnya, sehingga kelebihan inilah yang direkomendasi oleh nasabahnya kepada orang lain.

(6) Terdapat pengaruh dan signifikan dari Kepercayaan, Komitmen Perusahaan, Komunikasi, Penanganan Konflik terhadap Loyalitas Nasabah Bank Sinarmas Cabang Mataram. Artinya semakin tinggi aspek kepercayaan dan komitmen, semakin efektif komunikasi dan penangan konflik yang dilakukan oleh Bank Sinarmas cabang Mataram akan menimbulkan efek semakin meningkatnya loyalitas nasabahnya.

\section{REKOMENDASI}

Adapun beberapa saran yang dapat direkomendasikan berdasarkan hasil penelitian adalah sebagai berikut:

(1) Loyalitas Nasabah dapat ditingkatkan dengan memperhatikan aspek kepercayaan dengan cara memberikan rasa aman kepada nasabahnya baik ketika melakukan transaksi maupun setelah transaksi, menunjukan sikap peduli terhadap pelanggan, memberikan pelayanan yang berkualitas, dan menepati janji terhadap pelanggan.

(2) Loyalitas Nasabah dapat ditingkatkan dengan memperhatikan aspek komitmen perusahaan dengan cara terus menerus melakukan pembelajaran untuk menyediakan kebutuhan pelanggan, menciptakan hubungan yang erat dengan pelanggan, dan terus menerus melakukan pembelajaran untuk menyediakan kebutuhan pelanggan.

(3) Loyalitas Nasabah dapat ditingkatkan dengan memperhatikan aspek komunikasi dengan cara memberikan informasi yang tepat dan dapat dipercaya, menyampaikan informasi mengenai adanya perubahan jasa yang ditawarkan, melakukan komunikasi yang proaktif ketika terjadi masalah antara perusahaan dan pelanggan.

(4) Loyalitas Nasabah dapat ditingkatkan dengan memperhatikan aspek penanganan konflik dengan cara mencegah hal-hal yang dapat menimbulkan konflik dalam memberikan pelayanan, meminimalkan dampak dari konflik yang timbul, dan mampu menyelesaikan konflik nyata yang sudah terjadi.

\section{DAFTAR PUSTAKA}

Aaker, D. A. (1991). Managing Brand Equity Capitalizing on the Value of the Brand Name. New York: The Free Pass.

Aaker. 2004. Marketing Research 8th Edition. John Wiley.

Blut, M., Evanschitzky, H., Vogel, V. \& Ahlert, D. (2007). Switching barriers in the fourstage loyalty model. Advances in Consumer Research. 34, 726-734. 


\section{$\int M M$ JURNAL MAGISTER MANAJEMEN UNRAM VOL. 6 No. 1 MARET 2017}

Buchari Alma. 2007. Manajemen Pemasaran dan Pemasaran Jasa. Bandung : Alfabeta.

Deluxe For Business. (2009, March). Creating a great customer experience. www.deluxe.com/shopdeluxe/ /9027_ Customer\%20Experience.pdf

East, R., Sinclair, J., \& Phil, G. (2000). Loyalty: definition and explanation. ANZMAC 2000. 286-290.

Enjelita, J., (2013), Analisis Korelasi Pengaruh Strategi Komunikasi Pemasaran Terhadap Loyalitas Pelanggan Lopecoffee Coffee Shop Di Samarinda, eJournal Ilmu Komunikasi, 2013,1 (4): 268-277, ISSN 0000-0000, ejournal.ilkom.fisip-unmul.ac.id.

Fasochah, dan Harnoto (2013), Analisis Pengaruh Kepercayaan Dan Kualitas Layanan Terhadap Loyalitas Pelanggan Dengan Kepuasan Konsumen Sebagai Variabel Mediasi (Studi Pada Rs Darul Istiqomah Kaliwungu Kendal), Jurnal Ekonomi Manajemen Akuntansi - ISSN 0853 - 8778 No. 34 / Th. XX / April 2013.

Griffin Jill (2005). Customer loyalty, How to earn it now to keep it. Singapore:lexington books

Herdian, G., dan Widyastuti, (2013), Pengaruh Relationship Marketing Terhadap Loyalitas Pelanggan Pada Nasabah Bank Btpn Kcp Sepanjang, Jurnal Ilmu Manajemen| Volume 1 Nomor 2 Maret 2013, Fakultas Ekonomi,Universitas Negeri Surabaya.

Juvonen, S. \& Lahtinen, T. (2010). Investigation of the factors influencing the level of customer satisfaction of the Club Tax-free members at KappAhl Lappeenranta. Laurea University of Applied Sciences.

Khadraoui, M., Gharbi, J.E., \& Plaisent, M. (2007). The causal chain of loyalty. Jendouba University.

Kotler, Philip. 2002. Manajemen Pemasaran, Analisa perencanaan, Implementasi dan control, Edisi Kesembilan, Jilid 1 dan jilid 2, Jakarta, Prehalindo, alih bahasa oleh Hendra Teguh S.E.,A.K., dan Ronny A. Rusli, S.E.

Malhotra. 2006. Basic Marketing Research. Prentice Hall.

Moisescu, Ovidiu I. (2006). A conceptual analysis of brand loyalty as core dimension of brand equity. Babes Bolyai University.

Narayandas, Das. (2005, September). Building loyalty in business markets. Harvard Business Review.

Nasermoadeli, Amir, Kwek Choon Ling \& Farshad Maghnati (2013) Evaluating the Impacts of Customer Experience on Purchase Intention, International Journal of Business and Management; Vol. 8, No. 6, 128-135. 


\section{JMM $\begin{gathered}\text { JURNAL MAGISTER MANAJEMEN } \\ \text { UNIVERSITAS MATARAM }\end{gathered}$ UNRAM VOL. 6 No. 1 MARET 2017}

Nauman, E., Williams, P., \& Khan, M.S. (2009). Customer satisfaction \& loyalty in B2B services. The Marketing Review. 9.4, 319-333.

Nidyatantari, Suryawardani, dan Agung (2016), Pengaruh Kepuasan dan Kepercayaan terhadap Loyalitas Konsumen Kedelai Jepang Edamame Pendekatan Structural Equation Modeling , E-Jurnal Agribisnis dan Agrowisata ISSN: 2301-6523 Vol.5, No.1, Januari 2016

Safitri, (2011), Kepercayaan, Komitmen, Komunikasi, Penanganan Konflik, Dan Perannnya Terhadap Kepuasan Terhadap Loyalitas Nasabah Bank Bca Di Surabaya, Journal of Business and Banking Volume 1, No. 2, November 2011, pages 117 - 130, STIE Perbanas Surabaya.

Sarwono, J., 2007, Analisis Jalur untuk Riset Bisnis dengan SPSS, Yogyakarta : Andi Offset.

Setiawan Dan Ukudi (2007), Pengaruh kualitas layanan, kepercayaan dan komitmen terhadap loyalitas nasabah (studi pada pd. Bpr bank pasar kendal), Jurnal Bisnis dan Ekonomi (JBE), September 2007, Hal. 215-227, ISSN: 1412-3126, Vol. 14, No.2

Setyawan, P., (2013) Pengaruh Kepercayaan, Komitmen, Harga Dan Keluhan Pelanggan Terhadap Loyalitas Pelanggan Kantor Pos Surakarta, Abstrak.

Sheth, J.N., \& Park, C.W. (1974). A theory of multidimensional brand loyalty. University of Illinois.

Silalahi, Ulber. (2010). Metode Penelitian Sosial. Jakarta: Refika Aditama.

Sugiyono, 2008. Metode Penelitian Bisnis. Edisi keduabelas. Bandung: Alfabeta . (2009). Metode Penelitian Bisnis. CV.Alfabeta, Bandung.

(2012). Metode Penelitian Kuantitatif Kualitatif dan RED. CV.Alfabeta, Bandung.

Supit, Mandey, dan Moniharapon (2015), Pengaruh Dimensi Kepercayaan, Komitmen, Komunikasi, Dan Penanganan Keluhan Terhadap Loyalitas Pelanggan Otomoto Manado, Jurnal EMBA Vol.3 No.2 Juni 2015, Hal. 194-204, ISSN 2303-1174.

Suwono, Antoni (2011), Customer Experiencedan Kaitannya Dengan Loyalitas Konsumen Hoka Hoka Bento: Perspektif B2C, Tesis Program Magister Manajemen Fakultas Ekonomi, Universitas Indonesia.

Tjiptono, F., 2000, Manajemen Jasa, Penerbit Andi Yogyakarta

Tjiptono, Fandy, 2008. Manajemen Jasa, Edisi keenam, Yogyakarta: Andi 